\title{
DIFFERENCES IN FISHERY AND AQUACULTURE PRODUCTS, THEIR PRODUCTION AND SALE TECHNICAL REGULATIONS IN EURASIAN ECONOMIC UNION AND LEGISLATION AND PRACTICE OF THE EUROPEAN UNION
}

\author{
Mihails Silovs ${ }^{1}, \mathrm{PhD}$ candidate; Olga Dmitrijeva², MRes \\ 1, 2 Latvia University of Life Sciences and Technologies
}

\begin{abstract}
The mandatory requirements for the fishery and aquaculture products, their production and sale in force in the territory of the Customs Union of the Eurasian Economic Union (CU EAEU) arise from the regulatory and legal acts of the Eurasian Economic Union and its predecessor - the Customs Union - and apply in a package approach similar to the law of the European Union pertaining to the food safety area. The requirements of the EAEU technical regulations have been analysed taking into account that European exporting enterprises are first of all obliged to comply with the requirements of the listed EU regulatory and legal acts applicable to their production process and products. The aim of this paper was to run a comparative analysis on the mandatory requirements of the food legislation of the European and Customs Unions regarding fishery and aquaculture products, their production and sale. The issues of certification of certain product categories are analysed separately, the requirements for canned fish being highlighted. The analysis is relevant for all fish processing companies which may consider the possibility of starting export to the countries of the CU EAEU and are intended to reduce costs associated with products' entry into these markets.
\end{abstract}

Key words: fishery, aquaculture, legal framework, international trade, fish exports.

JEL code: F13, F42

\section{Introduction}

Currently, the issue of food safety remains principal both for end consumers and for regulatory institutions (Beulens et al., 2005; Trienekens and Zuurbier, 2008). The World Bank group in their analysis of some requirements of the European Union and the Customs Union food legislation (2015) highlight a joint responsibility of the state and industry for ensuring food safety. At the same time, sustainable production in the food sector for such comparatively small markets as Latvia is certainly associated with the constant expansion and retention of export markets.

Access to food export markets depends largely on the capacity of food companies to upgrade their levels of conformity with export market requirements (Weyandt et al., 2011; Kussaga et. al., 2013). The attention that food safety and consumer protection enjoy on the agenda of governments seeking to expand their trade links with other countries has been continuously growing. Likewise, food businesses interested in expanding their export destinations have to understand the quality and safety requirements of their target markets. Failure to meet conflicting demands of the export market (such as regulation, microbiological criteria, chemical standards, and inspection) can result in a reduced export potential, in particular product abandonment due to non-compliance with local legislation.

The Customs Union of the Eurasian Economic Union includes Russia, Belarus and Kazakhstan, which is a significant existing and potential market for the export of fish and aquaculture products produced in the EU, including Latvia. In this context, set of requirements for imported fish and aquaculture products is formed by "horizontal" technical regulations (TR) - TR CU 021/2011 "On food safety", TR CU 022/2011 "Food products in terms of their labelling", TR CU 005 / 2011 "On the safety of packaging", TR CU 029/2012 "Requirements for the safety of food additives, flavourings and other aids" - and the "vertical" technical regulation TR EAEU 040/2016 "On the safety of fish and fish products", the provisions of which should be considered as exclusively interrelated.

The lists of measurement methods used to confirm the compliance of products with the requirements of technical regulations are approved by the relevant decisions of the Customs Union Commission or the

1 Corresponding author: Mihails Silovs, mihails.silovs@gmail.com 
Board of the Eurasian Economic Commission. The lists of interstate and national standards containing requirements for products are approved by the same decisions; products manufactured in accordance with those are automatically considered to comply with the requirements of technical regulations and are not subject to increased supervision by the competent authorities.

The classification of types of fish food products regulated by the EAEU TR 040/2016 is provided at sections 1 and 2 of this regulation. There is no responsible body for issuing official clarifications and comments on the requirements of legal acts in the structure of the EAEU. All comments of the EAEU Commission are for informational purposes only and may be rejected by both the executive and judicial authorities of the EAEU member states.

The aim of this work was to conduct a comparative analysis on the mandatory requirements of the food legislation of the European and Customs Unions regarding fishery and aquaculture products, their production and sale. The purpose of this comparative analysis is to provide food processing companies with information on the specifics of EU and CU legal requirements, to help evaluate and expand their potential to meet these requirements and enter new export markets. Tasks of the research include analysis of the application of procedures based on HACCP principles, requirements for the use of particular ingredients in fish products, the information provided for the labelling of fish products, as well as the requirements for enterprises and foreign enterprises certification procedure for compliance with the EAEU technical regulations. The research implemented a qualitative research methodology based on the comparative analysis of the relevant EAEU and the EU regulations. The hypothesis of the study: "There are differences in the EU and EAEU regulations that should be considered by EU food processing companies willing to expand to relevant markets". All the differences in the requirements of the EAEU technical regulations discussed in this article are given taking into account that European exporting enterprises, first of all, are obliged to comply with the requirements of the internal EU regulations. The sources of information included legislation acts of EAEU and EU regulating import, production and sale of fishery and aquaculture products.

\section{Research results and discussion}

\section{Requirements for the application of procedures based on HACCP principles}

According to clause 2 of Art. 10 TR CU 021/2011, the manufacturer, while carrying out food production (manufacturing) processes related to the safety requirements of such products, must develop, implement and maintain procedures based on the principles of HACCP.

TR EAEU 040/2016 does not contain independent requirements for the development and implementation of procedures based on the principles of HACCP - it makes use of reference practice. Thus Art.13 requires fishery products to comply as well with the safety requirements set in TR CU 021/2011, and Art. 253 requires the safety of products in the process of their production to be ensured through the functioning of the safety system (production control), while the particular requirements are contained in Art. 10 and Art. 11 TR CU 021/2011.

The technical regulations of the EAEU, unlike Regulation (EC) No. 852/2004 of the European Parliament and of the Council of 29.04.2004, do not provide for the drawing up of guidelines for the development and implementation of self-control systems at the supranational, national or industrial levels - therefore, all the requirements contained in them, must be executed literally. At the same time, supervisory authorities do not consider availability of an implemented food safety management system in accordance with ISO 22000 as proof that the requirements of TR CU 021 in terms of the production control system are met. 
Also, unlike Regulation (EU) No. 852/2004, all requirements of TR CU 021/2011, including those for production control system, apply as well to organizations involved in the production of primary products, i.e., for example, to fishing vessels of coastal fishing, not processing the catch on their own.

The very principles of HACCP as set forth in Part 3 of Art. 11 TR CU 021/2011 differ from those stated in the standard CAC / RCP 1-1969. In particular, clause 3.5) does not require the initiation of corrective actions in case of violation of critical limits, but rather the establishment of a course of action - which is a broader concept and, obviously, involves actions related to the recall of unsafe products. The requirements of clause 3.6) do not relate to inspections of the production control system as such (using internal audits and other verification methods), but establish frequency of inspections for compliance with the requirements of technical regulations only for products going into circulation.

The list of mandatory procedures, the implementation of which within the framework of the production control system is required by TR CU 021/2011, includes:

- the procedure for selecting the technological production processes necessary to ensure food safety;

- the procedure for selecting the sequence and flow of technological operations to prevent contamination of raw materials and finished products;

- the procedure for determining the controlled stages of technological operations and products at the stages of their production (manufacturing) in production control programs;

- the procedure for monitoring raw materials, technological equipment, packaging materials, products used in the manufacture of products, as well as the products themselves;

- the procedure for monitoring the functioning of technological equipment;

- the procedure for documenting information on the controlled stages of technological operations and the results of product control;

- the procedure for observing the conditions of storage and transportation of products;

- the procedure for maintaining production facilities, technological equipment and implements used in the production process in a condition that eliminates product contamination;

- the procedure for selecting ways to ensure that employees comply with the rules of personal hygiene;

- the procedure for selecting methods and establishing the frequency of cleaning, washing, disinfection, disinsection and deratization of industrial premises, technological equipment and implements used in the production process;

- the procedure for maintaining and keeping documentation confirming the compliance of the manufactured products with the requirements of technical regulations on paper and (or) electronic media;

- the procedure for traceability of food products.

The established retention period for documents confirming the safety of raw materials is three years from the date of their issue. The retention period for the remaining documents confirming the compliance of the production control system with the requirements of TR CU 021/2011 is not legally stipulated.

\section{Requirements for the use of individual ingredients in fish products}

TR EAEU 040/2016 establishes the minimum content of fish ingredients only for several types of products - it is standardized in their definitions, Art. 4. These types of products include:

- products for baby food ( 8 - $18 \%$ of muscle tissue of fish for products based on vegetable and fish products, 18 - $40 \%$ - for products based on fish and vegetable-based products, over $40 \%$ - for products based on fish products); 
- preserves (not less than $65 \%$ for preserves from salted fish, not less than $55 \%$ - for preserves from other aquatic organisms and caviar);

- canned food (at least $50 \%$ ).

The content of edible salt is regulated only in preserves - it may not exceed $8 \%$. A controversial point is the production of preserves from raw materials subjected to heat treatment: such products are allowed according to Appendix 1 TR EAEU 040/2016, but are not allowed according to the definition of the type of product "preserves". At the same time, GOST 30054-2003 "Canned food and preserves from fish and seafood. Terms and definitions" included in the list of standards to TR CU 021 allows the production of thermally processed preserves.

The ranking of the types of products that have undergone dehydration has been established, depending on the residual moisture content - it is also stipulated in the definitions in Art. 4:

- dried products - no more than $20 \%$;

- dried and sundried products - more than 20 and no more than $30 \%$;

- sundried products - at least $30 \%$.

TR EAEU 040/2016 in Art. 16 bans manufacture and sale of products made from the following families:

- Canthigasteridae (toothfish);

- Diodontidae (hedgehog-fish);

- Molidae (moon fish);

- Tetraodontidae (four-toothed).

With regard to the use of food additives, in comparison with Regulation (EC) No $1333 / 2008$ of the European Parliament and of the Council of 16.12.2008, CU TR 029/2012 contains the following different provisions:

- polyols (E420, E421, E953, E965, E966, E967, E968) are not permitted for use in any unprocessed products;

- citrates of sodium (E331), potassium (E332) and calcium (E333) are not allowed for use in unprocessed products;

- sulfurous acid (E220), sodium sulfite (E221), sodium hydrosulfite (E222), sodium pyrosulfites (E223), potassium (E224), potassium sulfites (E225), calcium (E226), calcium hydrosulfites (E227), potassium (E228) are allowed in the amount of a single norm for fresh and frozen crustaceans of the families Penaeidae, Solenoceridae, Aristaeidae in the amount of $300 \mathrm{mg} / \mathrm{kg}$ of edible part;

- 4-hexyleneresorcinol (E586) is not approved for use in the EAEU;

- dyes are not allowed in unprocessed products;

- the content of brown HT (E155) in semi-finished products cooked from crustaceans is allowed no more than $250 \mathrm{mg} / \mathrm{kg}$;

- sorbic acid (E200) and potassium sorbate (E202) are not allowed for use in ready-made aspic dishes;

- the content of sorbic acid (E200), sodium sorbates (E201), potassium (E202), calcium (E203), benzoic acid (E210), sodium benzoates (E211), potassium (E212) and calcium (E213) in combination is allowed for use in boiled Crangon crangon and Crangon vulgaris at a level of $2000 \mathrm{mg} / \mathrm{kg}$, including not more than $1000 \mathrm{mg} / \mathrm{kg}$ benzoates;

- sulfurous acid (E220), sodium sulfite (E221), sodium hydrosulfite (E222), sodium pyrosulfites (E223), potassium (E224), potassium sulfites (E225), calcium (E226), calcium hydrosulfites (E227), potassium 
(E228) are allowed in the amount of a single norm for boiled crustaceans of the families Penaeidae, Solenoceridae, Aristaeidae in the amount of $270 \mathrm{mg} / \mathrm{kg}$ of edible part;

- sodium nitrates (E251) and potassium (E252) are allowed in salted herring and sprat and in marinade at the level of $200 \mathrm{mg} / \mathrm{kg}$ in terms of sodium nitrite;

- extracts of rosemary (E392) are allowed in a single norm - $150 \mathrm{mg} / \mathrm{kg}$ (per fat of the product) in terms of the sum of carnosol and carnosic acid;

- pyrophosphates (E450), triphosphates (E451), polyphosphates (E452) are not allowed for use in any salted fish, including the Gadidae family (saithe - Pollachius virens and pollock - Theragra chalcogramma), which is allowed by Regulation (EC) 1133/2008 as amended in 2019;

- stevioglycosides (E960) are not allowed for use in fish products;

- neotame (E961) is not approved for use in fish products;

- advantame (E969) are not allowed for use in the EAEU;

- amaranth (E123) is not approved for use in the EAEU;

- boric acid (E284) is not approved for use in the EAEU;

- sodium tetraborate (borax) (E285) is not approved for use in the EAEU.

\section{Requirements for information submitted for labelling of fish products}

The requirements for the labelling of fishery products are regulated by both TR CU 022/2011 and TR EAEU 040/2016 at the same time. The differences compared to Regulation (EC) No 1169 | 2011 of the European Parliament and of the Council of 25.10.2011 are as follows.

All information on the label, except as otherwise specified, must be in Russian.

Information about products is not meant to be communicated through verbal means. It should be noted, that the entire text of the marking must be displayed in a font with a lowercase letters' height of at least 2 $\mathrm{mm}$.

The name of fishery products must necessarily include:

- the name of the type of product (refer to the list in clause 2a of TR EAEU 040/2016);

- zoological name of the used raw aquatic materials in Russian;

- type of cutting;

- type of processing (salted, smoked etc.). Processing according to TR EAEU 040 (clause 4, article II) includes "heat treatment (except for freezing and cooling), smoking, canning, maturation, salting, drying, pickling, concentration, extraction, extrusion or a combination of these processes." As per the same clause, products that have not been processed are classified as unprocessed (frozen, chilled, minced meat, a number of semi-finished culinary products etc.);

- Imitation information - for imitated products.

It is not allowed to indicate components in the product name if the product does not contain such components or products resulting from their processing. If the product contains a flavouring agent, then the name of the component replaced by this flavouring agent and not being part of the product may be included in its name using the words "with taste of" and (or) "with flavour of".

To determine zoological name of a type of raw material, the EAEU Commission proposes the following documents for guidance:

- Commercial fish of Russia (Gricenko, Kotljar, Kotenyov, 2006);

- Handbook on the chemical composition and technological properties of marine and oceanic fish (Bykov, 1999); 
- Atlas of lifetime colouring of the cephalopods (portraits of cephalopods) (Alexeev, 2013);

- Guidebook-identifier of commercial and mass cephalopods of the World Ocean (Filippova et. al., 1997);

- Fish of the Atlantic (Hlopnikova, 2010);

- Atlas of distribution of fish and pisciform (drawings of fish, maps of ranges and comments) (Mikulin, Kotenyov, 2007);

- Illustrated guide to Decapoda of the Atlantic sector of Antarctica and adjacent waters (Anosov, 2012);

- A five-language dictionary of the names of animals (fish), Latin, Russian, English, German, French (Reshetnikov et al., 1989);

- Dictionary of names of marine food fishes (Berdichevsky, 1980);

- Order of the Ministry of Agriculture of Russia dated 16.10.2012 No. 548 "On approval of the lists of types of aquatic biological resources subject to industrial fishing and coastal fishing".

Should none of the listed sources contain the name of the species of interest in Russian, then the importer or manufacturer, in accordance with established practice, will address one of the branches of the All-Russian Institute of Fisheries and Economy (VNIRO) with an official request with a view to establish if Russian name corresponds to the available scientific name (Latin).

When specifying the composition of the product, within the mandatory data that the marking must contain:

- the presence of a vacuum (except for canned food);

- use of fish with spawning changes (in the production of canned food);

- information on freezing or refrigerating of products;

- the words "made from frozen raw materials" - for products made with the use of frozen raw materials;

- the words "ready-to-eat products" - for culinary products. Note that attention should be paid to the definition of the term set by Art. 4 TR EAEU 040/2016: fish culinary product - fish food products made with or without the addition of food components and (or) food additives, ready for eating after heat treatment or without it;

- canned food must contain the following marking applied by means of embossing or indelible paint: production date (six digits), shift number (one digit), fishing industry index (letter "P") with a gap of one or two characters between them;

- information about the ingredients obtained with the use of GMOs;

- the Eurasian Conformity mark on the EAEU market.

- immediately preceding indication of the list of components, there should be placed inscription "Composition";

- if the mass fraction of a constituent compound component is not more than $2 \%$, it is allowed not to indicate the components included in it, with the exception of food additives, flavourings and their constituent food additives, biologically active substances and medicinal plants, components obtained with the use of GMOs and components, which are the most common allergens (clause 14, part 4.4 of article 4 of CU TR 022/2011 - there are differences from Appendix 2 of Regulation (EU) 1169/2011);

- when listed as part of the names of types of products, the names of some components can be replaced - see Appendix. 1 TR CU 022/2011;

- for products packaged using a modified atmosphere, the composition of such environment is indicated. When specifying the quantity of products, the following differences should be noted: 
- the net mass must be indicated without any exception, since the provisions on products subject to loss of mass or volume during storage do not apply;

- if the packaged product consists of several consumer packages with products of different types and names and (or) individual products of various names, then the name and quantity of products of each consumer package and (or) the name, number of pieces, or weight of each should be indicated on the group packaging of the packaged products;

- undefined indication of the quantity of packaged products and an indication of the range of values for the quantity of packaged products is not allowed;

- for frozen products, the net weight without glaze and the mass fraction of glaze are indicated as percentage.

The production dates of products are indicated using the words:

- "production date" indicating the hour, day, month with a shelf life of up to 72 hours;

- "production date" indicating the date, month, year with an expiration date of 72 hours to 3 months;

- "production date" indicating the month, year or date, month, year with an expiration date of 3 months and more.

After the words "production date", the date of product manufacture or the place where this date is applied to the consumer package is indicated. The words "production date" may be replaced by the words "manufacture date" or wording of the same meaning. In addition, for products packed outside the place of production the date of packaging is indicated.

When specifying the expiration date, the following words should be used:

- "best before" indicating the hour, day, month, with an expiration date of up to 72 hours;

- "best before" indicating the date, month, year, if the shelf life is from 72 hours to 3 months;

- "best until the end of" with the indication of the month, year or "best before" with the indication of the date, month, year if the shelf life is at least 3 months.

It is allowed to use the word "best" with indication of the number of days, months or years, or if the shelf life is up to 72 hours, the word "best" with indication of the number of hours.

The words "best before", "best", "best until the end" in the product labelling may be replaced by the words "expiration date", "use before" or wording similar in meaning.

Instead of the place of origin or country of origin of the product, the name and location of the product manufacturer and importer should be indicated. In this case, the officially registered name and location (address, including country) of the manufacturer are used. Should it appear not the same as the manufacturer's address, the address(-es) of the production(-s) is indicated too. Information on the name and location of the manufacturer of products supplied from third countries may be indicated in Latin letters and Arabic numerals or in the state language(-s) of the country of the food manufacturer location, provided that the name of the country is indicated in Russian.

In contrast to the requirements of the Commission Executive Order (EU) 2018/775 of 28/05/2018, the indication of the FAO catch area or inland water catch area is mandatory only for unprocessed products. In this case, an appropriate indication of the aquaculture origin of unprocessed products is mandatory.

Products packaged outside the place of their manufacture (except for the cases of food products being packaged in consumer packaging by retail stores) must contain specified information both on the manufacturer and on the packer of the product, including cases when the packaging was ordered by some other organization. 
When indicating nutritional and energy value, the amount of vitamins and minerals may be indicated if they were added during production or if their native content is at least $5 \%$ of the daily requirement in $100 \mathrm{~g}$ or $100 \mathrm{ml}$, or in 1 serving of products (refer to Appendix 2 to TR CU 022/2011, the differences are in the recommended nutrient standards).

The values of indicators of nutritional and energy value should be rounded as per the rules set out in Appendix. 3 TR CU 022/2011. Their indication may be accompanied by the words "average value".

In the manufacture of products from raw materials obtained from GMOs, GMO lines that have passed state registration in the EAEU countries must be used.

For products obtained with the use of GMOs, including those not containing DNA and protein, the following information must be indicated: "genetically modified products", or "products obtained from genetically modified organisms", or "products contain components of genetically modified organisms".

In such cases, next to the Eurasian Conformity mark, a marking sign of the same shape and size is applied in the form of the inscription "GMO".

The content of GMO not exceeding $0.9 \%$ in products is considered an accidental or technically unavoidable impurity, and such products do not belong to food products containing GMOs. When labelling such food products, information as to the presence of GMOs is not indicated.

For products obtained from genetically modified microorganisms (GMM) or with their use, the following information is required:

- for those containing viable GMM - "The product contains viable genetically modified microorganisms";

- for those containing non-viable GMM - "The product is obtained using genetically modified microorganisms";

- for those freed from the content of technological GMM or for those obtained using components freed from the content of GMM - "The product contains components obtained with the use of genetically modified microorganisms."

In product labelling, information on the presence of GMOs is not indicated in relation to used technological aids made from or using GMOs.

For processed packaged products, no cases of omitting mandatory information from the labelling are allowed. If the area of the larger side of the consumer package does not exceed $10 \mathrm{~cm}^{2}$, then

- name,

- production date,

- shelf life and storage conditions,

- quantity of products,

- the name and location of the manufacturer, as well as the name and location of the importer,

- recommendations or restrictions on the use of products,

- indicators of nutritional value,

- information on the presence of components obtained with the use of GMOs,

- The Eurasian Conformity mark a single sign of circulation on the EAEU market must be applied to the consumer packaging and (or) on the label and (or) a leaflet placed in each consumer or transport package, or attached to each consumer or transport package.

It is enough for the marking of the transport packaging in Russian to contain:

- product name,

- quantity of products, 
- production date,

- shelf life,

- storage conditions,

- information allowing to identify the batch,

- name.

Before delivering products to the EAEU market, it is advisable to carry out an examination of the labelling.

\section{Requirements for enterprises}

Requirements for equipment, implements, transport, organization of production facilities and engineering systems, for the provision of energy carriers (water, ice, steam etc.) of coastal enterprises are regulated by TR CU 021/2011, which do not differ from the requirements of App. II of Regulation (EC) No $852 / 2004$.

Requirements for the design features of production and processing vessels of various classes are specified in the EAEU TR 040/2016 and contain one significant difference compared to the requirements of Sec. VIII adj. III of Regulation (EC) No 853/2004 of the European Parliament and of the Council of 29.04.2004, namely: for vessels engaged in the production of chilled crustaceans and molluscs, no exception has been made in terms of minimum design solutions compared to processing vessels.

Technical regulations do not provide for and do not contain references to additional documents that determine the requirements for the design features of processing plants. In practice, supervisory authorities may impose requirements of national construction rules and regulations, aimed primarily at the safety of the construction and operation of structures, rather than at the sanitary and hygienic condition of production.

\section{The procedure for certification of foreign enterprises for compliance with the technical regulations of the EAEU}

In the public domain, to be specific, on the Russian Federal Service for Veterinary and Phytosanitary Surveillance website, there is no information on the foreign enterprises examining procedure for their production activities and products compliance with the requirements of the applicable EAEU technical regulations. Based on the common practice, the lists of importing enterprises are still prepared for the EAEU side by the competent national authorities of the exporting countries.

The possibility of engaging Russian expert commissions in the certification procedure survey should be discussed first on the level of the Russian Federal Service for Veterinary and Phytosanitary Surveillance regional administration of the planned delivery region. One should bear in mind necessity to carry out production of certain assortments and assortment groups of goods, taking into account the requirements of clauses 17, 18, 26 - 42 of the EAEU TR 040/2016, which provide a list of national GMP provisions.

\section{Certification of certain categories of products for any standards \GOST}

Requirements for voluntary certification of imported products can only originate from retail chains - this is exclusively a civil law agreement and cannot be considered a widespread practice. There are no such requirements on the part of the regulatory authorities - a mandatory conformity assessment is enough, as defined by Ch. XI TR EAEU 040/2016:

- for unprocessed products - in the form of a veterinary and sanitary examination conducted by the Russian Federal Service for Veterinary and Phytosanitary Surveillance, 
- for processed products - in the form of conformity declaration according to the diagram 4d,

- for products of a new type - state registration.

As per Art. 4 TR CU 021/2011, food products of a new type - food products (including food additives and flavourings) that were not previously used by humans for food in the territory of the EAEU, namely: with a new or deliberately changed primary molecular structure; consisting or isolated from microorganisms, microscopic fungi and algae, plants, isolated from animals, obtained from GMOs or with their use, nanomaterials and nanotechnology products; with the exception of food products obtained by traditional methods, which are in circulation and from practical experience are considered safe. Food products of a new type do not include food products manufactured according to well-known and already used technologies, which contain components, including food additives that are already used for consumption by humans, even if such products and components are manufactured according to new recipe.

State registration of a new type of product is termless and is carried out prior its initial commercial delivery to the customs territory of the EAEU by the territorial departments of the Russian Federal Service for Veterinary and Phytosanitary Surveillance at the location of the importer. The fact of state registration of a new type of product means that in future such food products are not subject to state registration by any other applicant and under other names.

Only a Russian person (importer) can be applicant when declaring, all tests must be carried out in a laboratory accredited by the Russian Accreditation and included in the unified register of EAEU conformity assessment bodies, using methods from the lists approved by the Decisions of the Customs Union Commission dated 09.12.2011 No. 880 and the EAEU Board No. 106 dated 29.08.2017.

Regarding the procedure for imported products testing with the aim of subsequent adoption of a declaration of conformity, a bilateral clarification was issued by the Federal Customs Service of Russia and Federal Accreditation Agency dated December 29, 2017.

In the event that product samples are imported into the territory of the EAEU for testing and the subsequent declaration of conformity adoption in order to extend its validity to deliveries under the concluded foreign trade contract, such samples must be declared as being subjected to the customs procedure for domestic consumption release. At the same time, a letter from the testing laboratory indicating the amount of products required to carry out the necessary tests is submitted to the customs authority. In the case of sampling from a commercial batch of products imported into the territory, such selection is carried out only by an act with the permission of the customs authority and on the basis of a letter from the testing laboratory indicating the required number of samples. As a rule, until the declaration is accepted, a commercial batch is not subject to release and is stored at the temporary storage warehouse.

It should be remembered that the list of safety indicators for any group of fish products in the EAEU is much wider in comparison with the EU requirements - this applies to both sanitary and hygienic and microbiological indicators, and the standardized levels and applied test methods are not equivalent. This also applies to the norms of nitrogen of volatile bases (clause 21 of the EAEU TR 040/2016), which is used as an indicator of the freshness of unprocessed products.

Taking this into account, it is advisable, before supplying products to the EAEU market to conduct a thorough expert study of the standardized indicators for a specific product and their determination methods.

\section{Additional requirements for canned fish}

Apart from the specific labelling requirements mentioned above, there are no additional provisions for canned fish production at onshore facilities. In terms of the production of canned fish on ships, there is a 
requirement (clause 38 of TR EAEU 040/2016) to have on them laboratory equipment and personnel to carry out production control - but this only in connection with natural canned fish liver products.

\section{Conclusions, proposals, recommendations}

1) The Customs Union of the Eurasian Economic Union and the European Union have established strict control over the safety of food products from fisheries and aquaculture, their production and sale. However, to ensure food safety, fundamentally different legal frameworks, regulatory methods, systems and control procedures are used.

2) The technical regulations of the EAEU, unlike the European regulations, do not provide for the drawing up of guidelines for the development and implementation of own control systems at the supranational, national or industrial levels - therefore, all the requirements that they contain must be met literally. In particular, availability of ISO 22000 system is not a proof that the requirements are met.

3) The list of safety indicators for any group of fish products in the EAEU is much wider in comparison with the EU requirements - this applies to both sanitary and hygienic and microbiological indicators, while the standardized levels and applied test methods are not equivalent. Taking this into account, it is advisable to conduct a thorough expert study of the standardized indicators for a specific product and their determination methods before supplying products to the EAEU market.

4) The regulation of the use of food additives is significantly different. The list of prohibited food additives according to TR CU 029/2012 is much wider in comparison with Regulation (EC) No. 1333/2008 of the European Parliament and of the Council of 16.12.2008.

5) There are significant differences in labelling used for fishery and aquaculture products. It is advisable to conduct an examination of the labelling prior to delivery of products to the EAEU market.

6) Requirements for voluntary certification of imported products can only originate from retail chains - this is exclusively an agreement within the framework of civil law and cannot be considered a common practice.

\section{Bibliography}

1. Alexeev D.O. (2013). Atlas prizhiznennyh okrasok golovonogih molljuskov. (Atlas of lifetime colouring of the cephalopods (portraits of cephalopods). VNIRO, 206 p., ISBN 978-5-85382-390-7.

2. Anosov, S. E. (2012). Illjustrirovannyj opredelitel Decapoda Atlanticheskogo sektora Antarktiki i prilegajushih vod. (Illustrated guide to Decapoda of the Atlantic sector of Antarctica and adjacent waters). VNIRO, 90 p., ISBN 978-5-85382-364-6.

3. Berdichevsky L.C. (1980). Slovar nazvanij morskih promyslovyh ryb. (Dictionary of names of marine food fishes). L. Nauka, 284 p.

4. Beulens, A. J., Broens, D. F., Folstar, P., \& Hofstede, G. J. (2005). Food safety and transparency in food chains and networks Relationships and challenges. Food control, 16(6), pp. 481-486.

5. Bykov, V. P. (1999). Spravochnik po himicheskomu sostavu i tehnologicheskim svojstvam vodoroslej, bespozvonochnyh i morskih mlekopitajushih. (Handbook on the chemical composition and technological properties of marine and oceanic fish). VNIRO, $262 \mathrm{p}$.

6. Codex Alimentarius Commission. (2003). Recommended International Code of Practice: General Principles of Food Hygiene, CAC/RCP 1-1969, Rev. 4-2003. Food and Agriculture Organization, Rome.

7. Commission Implementing Regulation (EU) $2018 / 775$ of 28 May 2018 laying down rules for the application of Article 26(3) of Regulation (EU) No 1169/2011 of the European Parliament and of the Council on the provision of food information to consumers, as regards the rules for indicating the country of origin or place of provenance of the primary ingredient of a food.

8. Filippova, J. A., Alekseev, D. O., Bizikov, V. A., and Hromov, D. N. (1997). Spravochnik-opredelitel promyslovyh i massovyh golovonogih molljuskov Mirovogo okeana. (Guidebook-identifier of commercial and mass cephalopods of the World Ocean). VNIRO, $272 \mathrm{p}$.

9. Gricenko, O.F., Kotljar, A.N. and Kotenyov, B.N. (2006). Promyslovye ryby Rossii. T. 2. (Commercial fish of Russia V.2). VNIRO, 1280 p., ISBN 5-85382-229-2.

10. Hlopnikova M.M. (2010) Ryby Atlantiki. (Fish of the Atlantic). M.: Terra Baltika, 196 p. 
11. Konservy, preservy iz ryby i moreproduktov. Terminy i opredelenija. (Canned food and preserves from fish and seafood. Terms and definitions). GOST 30054-2003.

12. Kussaga, J. B., Luning, P., Jacxsens, L., \& Tiisekwa, B. (2013). Diagnosis of Food Safety Management Systems Performance in Food Processing Sectors for Export and Domestic Markets. African Journal of Food Science and Technology, 4(10), pp. 240-250.

13. Mikulin A.E., Kotenyov B.N. (2007). Atlas rasprostranenija ryboobraznyh i ryb (risunki ryb, karty arealov $i$ kommentariiju). (Atlas of distribution of fish and pisciform (drawings of fish, maps of ranges and comments). VNIRO publishing house, $176 \mathrm{p}$.

14. Prikaz Minselhoza Rossii ot 16.10 .2012 № 548 «Ob utverzhdenii perechnej vidov vodnyh biologicheskih resursov, $v$ otnoshenii kotoryh osushestvljaetsja promyshlennoe rybolovstvo i pribrezhnoe rybolovstvo». (Order of the Ministry of Agriculture of Russia dated 16.10.2012 No. 548 "On approval of the lists of types of aquatic biological resources subject to industrial fishing and coastal fishing.").

15. Razjasnenie Federalnoj tamozhennoj sluzhby Rossii i Rosakkreditacii o porjadke vvoza tovarov $v$ kachestve prob i obrazcov. 29.12.2017. (Federal Customs Service of Russia and Federal Accreditation Agency dated December $29,2017)$.

16. Regulation (EC) No 1333/2008 of the European Parliament and of the Council of 29 April 2004 on food additives.

17. Regulation (EC) No 852/2004 of the European Parliament and of the Council of 29 April 2004 on the hygiene of foodstuffs.

18. Regulation (EC) No 853/2004 of the European Parliament and of the Council of 29 April 2004 laying down specific hygiene rules for food of animal origin.

19. Regulation (EU) No 1169/2011 of the European Parliament and of the Council of 25 October 2011 on the provision of food information to consumers.

20. Reshenie Kollegii Evrazijskoj ekonomicheskoj komissii ot 29.08.2017 № 106 Perechen standartov po sobljudeniju trebovanij tehreglamenta EAÈS «O bezopasnosti ryby i rybnoj produkcii». 29.08.2017. (Decision of the Board of the Eurasian Economic Commission of August 29, 2017 No. 106 List of standards for compliance with the requirements of the EAEU technical regulations "On the safety of fish and fish products", signed on August 29, 2017).

21. Reshenie Komissii Tamozhennogo sojuza ot 09.12.2011 № 880 o prinjatii tehnicheskogo reglamenta Tamozhennogo sojuza "O bezopasnosti pishevoj produkcii". (Decision of the Customs Union Commission dated 09.12.2011 No. 880 on the adoption of the technical regulation of the Customs Union "On food safety").

22. Reshetnikov, J. S., Kotljar, A. N., Rass, T. S., and Shatunovskij, M. I. (1989). Pjatijazychnyj slovar nazvanij zhivotnyh. Ryby. (A five-language dictionary of the names of animals (fish), Latin, Russian, English, German, French). M.: Russkij jazyk, 734 p.

23. Sravnitelnyj analiz nekotoryh trebovanij pishevogo zakonodatelstva Evropejskogo sojuza i Tamozhennogo sojuza Rossii, Belarusi i Kazahstana World Bank Group (2015). Comparative analysis of some requirements of the European Union and the Customs Union food legislation. Retrieved: http://documents1.worldbank.org/curated/en/973611467993504462/pdf/98140-RUSSIAN-REPLACEMENT-WPPUBLIC-Box385193B.pdf. Access: 11.01.2021.

24. Tehnicheskij reglament Evrazijskogo ekonomicheskogo sojuza TR EAES 040/2016 O bezopasnosti ryby i rybnoj produkcii. (Technical Regulations of the Eurasian Economic Union TR EAEU 040/2016 On the safety of fish and fish products).

25. Tehnicheskij reglament Tamozhennogo sojuza TR TS 005/2011 «O bezopasnosti upakovki». (Technical Regulations of the Customs Union TR CU 005/2011 "On the safety of packaging").

26. Tehnicheskij reglament Tamozhennogo sojuza TR TS 021/2011 "O bezopasnosti pishevoj produkcii". (Technical Regulations of the Customs Union TR CU 021/2011 "On food safety").

27. Tehnicheskij reglament Tamozhennogo sojuza TR TS 022/2011 «Pishevaja produkcija v chasti ee markirovki». (Technical Regulations of the Customs Union TR CU 022/2011 "Food products in terms of their labeling").

28. Tehnicheskij reglament Tamozhennogo sojuza TR TS 029/2012 «Trebovanija bezopasnosti pishevyh dobavok, aromatizatorov $\mathrm{i}$ tehnologicheskih vspomogatelnyh sredstv». (Technical regulations of the Customs Union TR CU 029/2012 "Safety requirements for food additives, flavorings and technological aids").

29. Trienekens, J., \& Zuurbier, P. (2008). Quality and Safety Standards in the Food Industry, Developments and Challenges. International Journal of Production Economics, 113(1), pp. 107-122.

30. Weyandt, A. J., da Costa, S. R. R., Nunes, M. L., \& Gaspar, A. (2011). Environmental \& Food Safety Management Systems, According to ISO 14001 \& ISO 22000 in Fish Processing Plants: experiences, critical factors \& possible future strategies. Procedia Food Science, 1, pp. 1901-1906. 